\title{
PROTOCOLS FOR SUCCESSFUL TRANSLOCATION OF PTARMIGAN
}

\author{
Clait E. Braun ${ }^{1}$, William P. Taylor ${ }^{2}$, Steve E. Ebbert ${ }^{3}$, \\ Robb S. A. Kaler ${ }^{4,5}$, and Brett K. Sandercock ${ }^{4}$ \\ ${ }^{I}$ Grouse Inc., 5572 North Ventana Vista Road, Tucson, AZ 85750, USA \\ E-mail: sg-wtp@juno.com \\ ${ }^{2}$ Wildlife Vet Consulting, P. O. Box 110168, Anchorage, AK 99511, USA \\ ${ }^{3}$ US Fish and Wildlife Service, Alaska Maritime National Wildlife Refuge, \\ 2355 Kachemak Bay Drive, Suite 101, Homer, AK 99603, USA \\ ${ }^{4}$ Division of Biology, 116 Ackert Hall, Kansas State University, Manhattan, KS 66506, USA \\ ${ }^{5}$ Current address; US Fish and Wildlife Service, Anchorage, AK 99506, USA
}

\begin{abstract}
We developed procedures for successful capture, holding, transport, and release of ptarmigan (Lagopus spp.) based on field work in Colorado and Alaska during the last four decades. Use of improved translocation protocols led to successful establishment of new populations of White-tailed Ptarmigan (L. leucura) in four states, and reintroduction of Evermann's Rock Ptarmigan (L. muta) to Agattu Island in the Aleutian Archipelago, Alaska. One of six translocation efforts failed due to inadequate site knowledge and transport in the Wallowa Mountains, Oregon (1967-1969). Translocations of birds in the Sierra Nevada Mountains in California (1971-1972), Pikes Peak in Colorado (1975), Uinta Mountains in Utah (1976), New Mexico (1981), and to Agattu Island (2003-2006) in the western Aleutian Islands were site-specific and based on local knowledge (except in California). Procedures included capture of birds with noosing poles and ground nets at different times of year; holding birds under cool, quiet conditions for the shortest time possible ( $<3$ days), rapid transport, and release into vacant or restored habitats that were suitable for ptarmigan. Numbers of birds and sex ratios per release varied, and spring transplants of breeding birds were most successful. Post-release monitoring of banded birds in Colorado, Utah, and banded and or radio- marked birds at Agattu Island provided critical insights that were useful in refining our protocols for future translocation of ptarmigan and other grouse. Received 31 December 2010, accepted 21 June 2011.
\end{abstract}

Braun, C. E., W. P. Taylor, S. E. Ebbert, R. S. A. Kaler, and B. K. Sandercock. 2011. Protocols for successful translocation of ptarmigan. Pages 339-348 in R. T. Watson, T. J. Cade, M. Fuller, G. Hunt, and E. Potapov (Eds.). Gyrfalcons and Ptarmigan in a Changing World, Volume II. The Peregrine Fund, Boise, Idaho, USA. http://dx.doi.org/10.4080/gpcw.2011.0313

Key words: Alaska, California, Colorado, New Mexico, Oregon, Utah, grouse, ptarmigan, translocations, protocols, reintroductions. 
Translocations of animals within North America have a long history (Leopold 1933) and have primarily involved game species of interest to hunters. In recent years, translocation efforts have also been an important tool for management of species of conservation concern, including Whooping Cranes (Grus americana), Masked Bobwhite (Colinus virginianus ridgwayi), and a variety of island birds (Ewen and Armstrong 2007, Reynolds et al. 2008). Objectives for translocation efforts are usually related to increasing the abundance, distribution, and genetic diversity of specific species and populations (Griffin et al. 1989). While an initial goal may have been to increase numbers of game species for hunters, modern goals are usually to restore or augment declining populations within their former habitats or to increase genetic diversity in small populations (Bouzat et al. 1998, Bellinger et al. 2003).

Grouse (Galliformes, Phasianidae, Tetraoninae) have also been translocated within North America with most early efforts directed at Greater Prairie-Chickens (Tympanuchus cupido) and Sharp-tailed Grouse (T. phasianellus) (Leopold 1933, Snyder et al. 1999), and later at reintroducing Ruffed Grouse (Bonasa umbellus) into former range (Rusch et al. 2000). All of the 12 species of grouse in North America have been translocated with varying success including Greater Prairie-Chicken (Schroeder and Robb 1993), Sharp-tailed Grouse (Connelly et al. 1998), Ruffed Grouse (Rusch et al. 2000), Spruce Grouse (Falcipennis canadensis) (Boag and Schroeder 1992), Sooty (Dendagapus fuliginosus) and Dusky Grouse (D. obscurus) (Zwickel 1992), Whitetailed Ptarmigan (Lagopus leucura) (Braun et al. 1978, Hoffman and Giesen 1983), Rock Ptarmigan (L. muta) (Kaler et al. 2010), and Willow Ptarmigan (Lagopus lagopus) (Hannon et al. 1998). Despite limited successes, translocation efforts have frequently failed including efforts with Greater Prairie-Chickens (Toepfer et al. 1990, Hoffman et al. 1992, Schroeder and Robb 1993), Lesser Prairie-Chickens (T. pal- lidicinctus) (Giesen 1998), Greater SageGrouse (Centrocercus urophasianus) (Musil et al. 1993), Gunnison Sage-Grouse (C. gunnisoni) (Reese and Connelly 1997), Dusky Grouse (Zwickel 1992), and Willow Ptarmigan (Hannon et al. 1998).

The objective of this work is to evaluate field protocols used as part of six translocation efforts for three species of grouse. We have been involved with attempts to establish new populations of White-tailed Ptarmigan in five states (California, Colorado, New Mexico, Oregon, Utah) and Ruffed Grouse (Alaska), and to reintroduce island populations of Rock Ptarmigan (Alaska). The objectives of this paper are to: (1) describe the methodology used in successful translocations (and establishment of new, continuing populations) of White-tailed Ptarmigan, (2) detail methods of re-establishment of a population of Rock Ptarmigan, and (3) identify reasons why one translocation of White-tailed Ptarmigan failed. We summarize suggestions for methodology and protocols that will be useful for future efforts to translocate ptarmigan into former, presently unoccupied habitats.

\section{Methods}

Field studies of the biology and population dynamics of White-tailed Ptarmigan were initiated in Colorado in 1966 (Braun and Rogers 1971), and led to a 40+ year project (Wang et al. 2002). The success of our field project encouraged other western states to contact the Colorado Division of Wildlife for wild-caught birds to be released into unoccupied or formerly occupied alpine habitats. Requests for translocations among western states were routinely approved, frequently in trade for other 'game' birds desired by Colorado.

Capture methods for ptarmigan were developed as part of ongoing research efforts in suitable habitats (Braun 1971). We determined that ptarmigan were territorial, socially monogamous, reliably nested each spring, and would 
renest if the initial clutch was lost early in laying or incubation. Thus, timing of initial translocation was focused on the territorial period prior to or at the start of egg-laying (late May-early June). We hypothesized that supplemental releases of additional birds (adults and chicks-of-the-year) prior to winter would be beneficial. Efforts were made to capture birds from several different mountain ranges for each release to ensure genetic diversity, even though we did not have data on genetic diversity of birds from different areas within Colorado. Captures were of individual birds using a noose pole snare (Zwickel and Bendell 1967). Attempts were made to capture and transport together both members of mated pairs and to release them simultaneously.

We initially had limited knowledge of the best methods to successfully hold live ptarmigan for transport and release of birds. However, most wildlife agencies had prior experience in translocating Ring-necked Pheasants (Phasianus colchicus), Gray Partridge (Perdix perdix), Chukar (Alectoris chukar), and a variety of species of quail (Odontophoridae). Our initial protocols were based on methods developed for other species of upland gamebirds. Upon capture, ptarmigan were placed into cotton holding bags, and we collected standard morphometric data to determine potential impacts of translocation. Birds were individually marked with leg bands, weighed to determine mass at capture, and examined for overall condition; linear measurements were recorded for tarsus, wing, and tail. We used plumage and wing molt to classify birds to age-class and gender. Birds were housed in four-compartment (no more than 2 birds per compartment), new cardboard poultry boxes (with multiple round holes to allow ample air flow) that had clean fiber matting. Poultry boxes were taped shut and placed in the shade for transport. Boxes with ptarmigan were transported at night via open bed pickup trucks to a commercial airport for air shipment to the state of destination. Air transport was conducted the day after capture with releases planned for the same or the following day (i.e., 2 days postcapture). Transport and release procedures varied among states and were conducted by helicopter or fixed-wing aircraft.

Follow up surveys were conducted in spring and fall in 1 or 2 years at two release sites. We used playbacks of tape-recorded calls during ground surveys to improve the probability of detection for low density populations of ptarmigan in alpine sites (Braun et al. 1973). Observations at another release area were made opportunistically by local personnel. All ptarmigan located were classified as males or females (adults) or females attending broods.

Captures of Evermann's Rock Ptarmigan ( $L$. $m$. evermanni) followed the same procedures (noosed, occasionally carpet-snared or netted, placed in cotton bags), but both pair members were rarely captured. Birds were banded, weighed, measured, classified to age and gender, and held in back-pack, three-compartment holding cages placed in a cool, secure building until transport by ship in the same holding cages. Cages had soft absorbent material on the floor and were cleaned daily. Small chunks of honeydew melon were provided during holding and transport. Some birds were held up to 3 days before shipment and release. The 4 -year study included 2 years of translocations only and 2 years where translocations were combined with intensive post-release monitoring of radio-marked birds (Kaler et al. 2010).

\section{RESUlTS}

We conducted translocations of White-tailed Ptarmigan into unoccupied habitats in five states (California, within Colorado, New Mexico, Oregon, and Utah). Evermann's Rock Ptarmigan were translocated from Attu Island into restored habitats at Agattu Island in the western Aleutian Islands; habitat restoration involved removal of Arctic Foxes (Vulpes lagopus), a nonnative predator which extirpated historic ptarmigan populations. Viable populations were established in five of six 
translocation efforts with the exception of the Wallowa Mountains, Oregon (Table 1).

Oregon (1967-1969)._Early translocations of ptarmigan from Taylor Pass, Thunder Pass, and Guanella Pass, Colorado to the Wallowa Mountains, Oregon were conducted over a 3year period (1967-69). We translocated 15 birds from Colorado in early September 1967 (15 birds; 8 adult and yearling males, 5 adult and yearling females, 2 chicks). An additional 21 birds (age/gender not recorded) trapped in Washington were released on 23 September 1967. Fourteen birds (3 adult and yearling females, 11 chicks) were shipped from Colorado on 4 September 1968. Transfer problems resulted in these birds being shipped to Portland and not Pendleton, and this group arrived in poor condition (4 dead, 6 weak, 4 in good shape). All live birds were released. Forty-four birds trapped in Washington were released on 7 (27 birds) and 8 (17 birds) September 1968 (age/gender not recorded). The last group (5 adult and yearling males, 11 adult and yearling females) released (all from Colorado) was captured on 5 April and released on 6 April 1969. Despite a large number (110) of birds released over a 3-year period, the transplant failed. Efforts to relocate ptarmigan in the release area were sporadic, but evidence of successful reproduction was observed during the translocation period (1-2 birds together, 1 hen with 4 chicks on 22 August 1969) (Vic Coggins, Oregon Department of Fish and Wildlife, pers. comm.). Occasional observations suggested the population may have persisted for a 20year period until 1989-1990 (Braun 1993). This translocation effort was considered failed because no reports of ptarmigan sightings have been made during the past two decades.

California (1971-1972).-Shipments of White-tailed Ptarmigan to California began in 1971 with transplantation of 10 birds on 23 August, 19 on 7-8 September, and 9 on 23 September 1971. An additional group of 23 birds was captured in breeding areas and shipped in April (17-18) 1972, and was fol- lowed by a second group of 12 birds on 5 September 1972. In total, 73 birds were released over 2 years (Table 1). At least two birds were released, unsuccessfully, from a fixed-wing aircraft in April 1972 (H. T. Harper, pers. comm.). All birds were released in the Mono Pass area and, by 1977-1979, ptarmigan were observed breeding in the Hall Natural Area with other records both south and north of the release area (Jack Slosson, pers. comm.). The translocation effort was successful because ptarmigan populations have now spread further north and south (G. P. Frederick, pers. comm.); they are now legally hunted in California and occur well north of Mono Pass and to Mt. Whitney on the south.

Colorado (1975).- Transplants (1975) to unoccupied habitat (Pike's Peak) in Colorado were accomplished in 1 year (spring and fall releases totaling 40 birds, Table 1) and were well documented in the published literature (Hoffman and Giesen 1983). The release was preceded by field investigations of the site (vegetation, rock and snow cover, moist sites). This population expanded quickly and breeding birds were found in all areas by 1979 . White-tailed Ptarmigan appeared to fully occupy all of the habitat available (at least 23 $\mathrm{km}^{2}$ ) and birds were known to be present and hunting was allowed at least through 1998.

Utah (1976). - White-tailed Ptarmigan were transplanted into the Uinta Mountains, Utah in 1976 following an environmental assessment and field investigations examining potential release sites in September 1975. Fifty-five birds were released during 3-4 June (23 birds, 11 mated pairs) and 3 September 1976 (32 birds) (Table 1). We released mated pairs in spring 1976 at distinct selected sites several hundreds of meters apart. Surveys in spring 1977 revealed paired, banded birds, as well as several unbanded yearlings (which were captured and banded). Field surveys in August 1977 located seven broods with an average of four chicks per brood. Translocation efforts were successful because White-tailed Ptarmi- 
Table 1. Ptarmigan transplants in western North America.

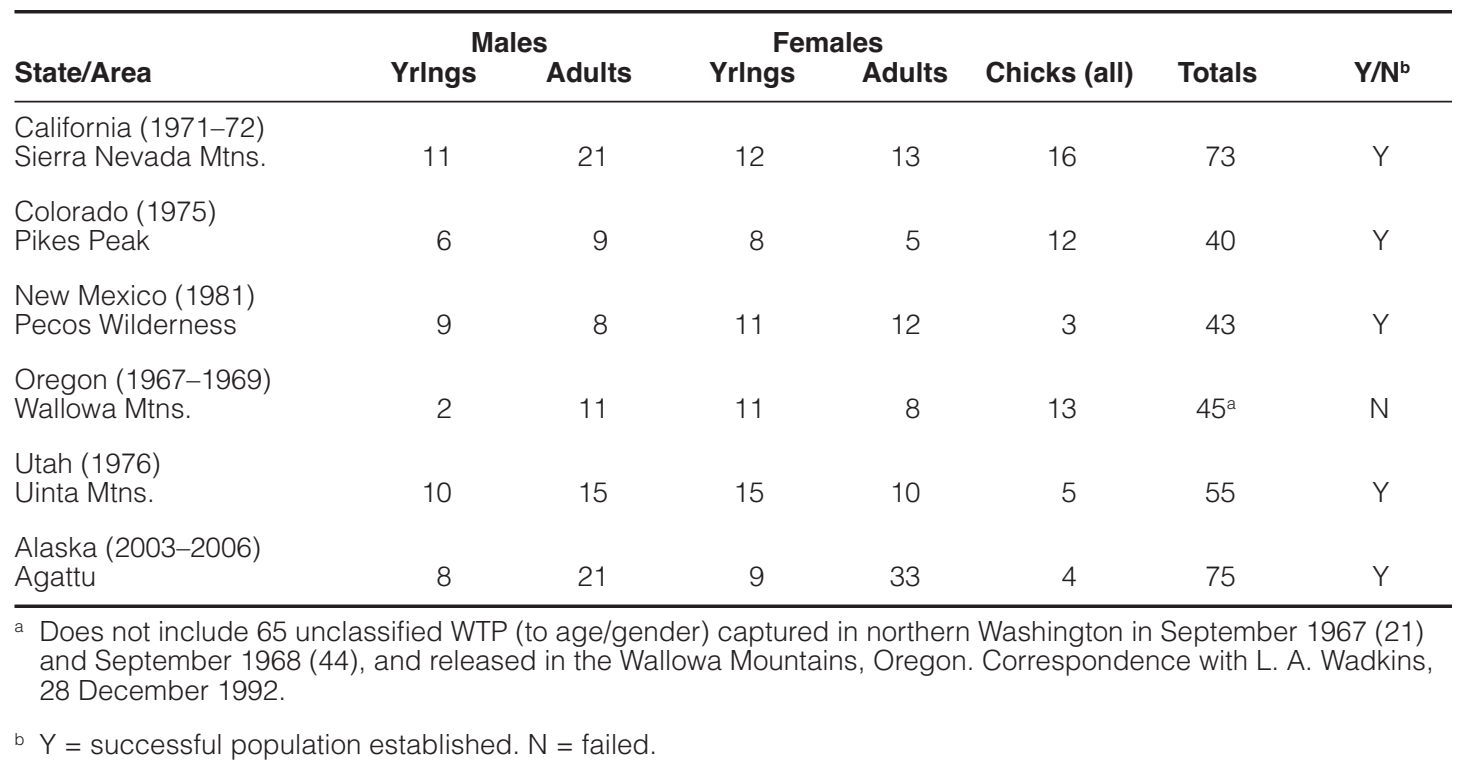

gan are now found throughout the alpine portions of the Uinta Mountains, Utah and are legally hunted (Braun et al. 1978).

New Mexico (1981).--Releases of Whitetailed Ptarmigan into the Pecos Wilderness in New Mexico were conducted in 1981. Fortythree birds (22 breeding birds [11 pairs] in May; and 21 mostly adults [ 3 chicks] on 9 September) (Table 1) were captured in Colorado, immediately flown to New Mexico and released within $24 \mathrm{hrs}$ of capture. Pre-release habitat investigations were conducted in the area selected for release in August 1979, but also earlier in September 1969. Two years post-release, reports of groups of up to 30 ptarmigan including unbanded adults and chicks were received near the release area in September 1983 (Leon Fisher, pers. comm.). Sightings of White-tailed Ptarmigan in New Mexico are uncommon (S. O. Williams, pers. comm.). Nevertheless, a limited survey effort during 12-14 June 2006 resulted in detections of at least three different males ( 1 captured and banded) and one female near the former release site above Serpent Lake (CEB). The translocated population of White-tailed
Ptarmigan in New Mexico has persisted for at least 25 years.

Alaska (2003-2006).-In our most recent effort, translocations were used to reintroduce Evermann's Rock Ptarmigan (L. muta evermanni) from Attu Island to Agattu Island in the Near Island group in the Western Aleutians. We captured and transplanted 75 ptarmigan (69 birds captured on breeding territories in late May-early June, 6 birds captured in September) over a 4 -year period (Table 1). Holding all birds for one or more days was necessary because of the desire to transport multiple individuals at one time. The western Aleutians is a remote area, and all transport of birds from Attu to Agattu was conducted with logistical support from a research vessel with the Alaska Maritime National Wildlife Refuge. Habitat restoration was completed by removal of an introduced population of arctic fox, and pre-release assessments of ptarmigan habitat at Agattu were considered unnecessary. Initial releases were conducted in 2003 and 2004 without any follow up surveys. Intensive postrelease monitoring of radio-marked birds in 2005-2006 showed that translocated birds 
quickly settled in alpine habitats and successfully nested within weeks of release. Annual surveys in 2007-2010 have found unbanded Evermann's Rock Ptarmigan providing evidence for successful reproduction and recruitment in the newly established population ( $\mathrm{R}$. S. A. Kaler, unpubl. data).

\section{Discussion}

From six translocation efforts during a 40-year period, we developed improved protocols for successful translocations of wild-caught ptarmigan. Admittedly, our initial efforts to introduce ptarmigan into unoccupied habitats were haphazard at best. Successful translocations of ptarmigan to California suggest Whitetailed Ptarmigan may be more plastic in their response to new habitats than expected. The best example of lack of knowledge and planning is the unsuccessful attempt to establish a population in the Wallowa Mountains, Oregon. The literature suggested the species was hypothetical in Oregon (Gabrielson and Jewett 1940), and the reports from Mt. Hood and Mt. Jefferson in the Cascade Range were discounted as there were no specimen records and the areas were isolated areas of alpine habitats. No efforts were made to assess the suitability of alpine habitats for ptarmigan in the Wallowa Mountains until 1992, 25 years after the initial release (Braun 1993). Ptarmigan were known to have survived in the Wallowa Mountains for up to 20 years despite poor timing of releases, poor selection of release sites, patchy habitats, and transport difficulties (Braun 1993). The transplant is considered to have failed as no birds were located in surveys by experienced personnel in 1992 despite the large numbers of birds released.

White-tailed Ptarmigan were absent from all mountain ranges in California prior to the releases of birds in 1971-1972. This successful transplant effort emphasized that grounddwelling birds should not be released from the air. Expansion of the released population seemed to be slow, but research by Frederick and Gutierrez (1992) indicated that ptarmigan had nevertheless expanded throughout much of the available habitats. However, suitable habitats were patchy in distribution, and access was frequently poor.

Despite the initial failure in the Wallowa Mountains, which was not known for almost 20 years, all other transplants of ptarmigan were successful as we further honed our methodology. Further, all successful translocations appear to be doing well and are unlikely to fail in the near term. We had concerns about the genetic composition of the transplant stock and made deliberate efforts to translocate birds from multiple mountain ranges within Colorado. Thus, every translocated population had at least some unrelated birds (especially females, as males in a given area were more likely than females to be related) (Giesen and Braun 1993). Birds originated within the central Rocky Mountains from Taylor Pass (Gunnison and Pitkin counties) in southwest Colorado to Thunder Pass (Jackson and Larimer counties) in northern Colorado.

Transplants of White-tailed Ptarmigan to Oregon included releases of birds from two different subspecies: L. l. altipetens from Colorado and L. l. leucurus/rainierensis from northern Washington. Releases of birds originating from different source populations could have contributed to the failure of the Oregon translocation. While genetic diversity is desirable, intermixing of different subspecies might have been problematic.

Speedy transport was important for successful translocations and, for the most part, it worked as designed. However, when a shipment went astray in Oregon, the result was dead and weak birds. This particular group contained mostly chicks which may have been more vulnerable to stress (11) (but classification of those dead [4] and weak [6] was not made at the release site). This reinforced the emphasis to avoid moving chicks in latter transplants unless they were mostly grown (late September). In our 
most recent translocation effort with Evermann's Rock Ptarmigan, we had only one handling-fatality during transport of 75 birds, a juvenile male which died of unknown causes. Two of 13 translocated females died within 2 weeks of release, one by drowning and one killed by a raptor (Kaler et al. 2010).

We had no experience in holding ptarmigan in captivity while waiting to transport birds to release locations. Thus, our intent was not to hold birds for more than $24 \mathrm{hrs}$. We became aware of the use of estradiol to help keep birds calm in captivity well after most of the translocations had occurred (Martin and Wright 1993). One of us (WPT) had extensive experience in capture, holding, and releasing Ruffed Grouse while transplanting this species into the Matanuska Valley and Kenai Peninsula areas in Alaska (Steen 1995, 1999). Both transplant efforts were successful, and releases in the Matanuska Valley greatly expanded the distribution of Ruffed Grouse over a large area. Our experience included holding birds prior to transport which required a method to provide moisture and nutrients. Thus, the use of small chunks of melons, specifically honey dew melon, was implemented. Ruffed Grouse readily ate bites of melons as did Evermann's Rock Ptarmigan when they were exposed to it. We are confident this reduced moisture loss and stress on captive birds.

We tried to capture mated pairs of ptarmigan starting with the work at Pike's Peak, Colorado and continuing with the translocations to the Uinta Mountains, Utah and the Pecos Wilderness in New Mexico. This practice worked well as did the actual selection of sites where pairs would be released. Subsequent breeding season surveys revealed that at least some pairs were still using the general locations where released. Our selection of sites at which to release pairs was based on our overall knowledge of the components of the breeding season requirements of White-tailed Ptarmigan (short and exposed shrub willow [Salix spp.], presence of several bare spots with emerging short green vegetation among the snowfields, and rocks of suitable size $[>20 \mathrm{~cm}$ but $<90 \mathrm{~cm}]$ ) (Braun 1971).

We were not overly concerned about dispersal from the release sites as all areas were of sufficient size to support ptarmigan. Our working assumption was that the birds released would find suitable habitats, if they occurred. All release areas had contiguous, frequently linear habitats, and we knew from our work in Colorado that ptarmigan frequently flew across canyons and even forested areas. Unlike Ruffed Grouse (Moran and Palmer 1963), ptarmigan can easily fly $>1.6 \mathrm{~km}$, although movement across large water expanses appears problematic despite observations of Willow Ptarmigan landing on water (Zimmerman et al. 2005). Post-release monitoring of Evermann's Rock Ptarmigan showed that birds quickly dispersed and settled in alpine areas at Agattu Island within 2 weeks of release (Kaler et al. 2010). If release site is not important to translocation success, it will aid logistics for release of birds under perilous coastal conditions in the remote islands of the Aleutian Archipelago.

There was no clear relationship of age (yearling or adults) or sex ratio with success of the translocations (Table 1). However, release of younger chicks should be discouraged as mortality of chicks of most gallinaceous birds is high. Release of balanced sex ratios seems intuitive, but male White-tailed Ptarmigan tend to live longer than females (Braun and Rogers 1971). Thus, it might be reasonable to transplant more females, if possible. Translocation of gravid females likely increased genetic diversity of the newly established population of Evermann's Rock Ptarmigan at Agattu Island because young carried alleles that likely originated from prior matings at Attu Island (A. J. Gregory, unpubl. data). Unfortunately, most translocation efforts are affected by how many birds can be captured in the shortest possible time with little possibility to sort through multitudes of potential candidates. Most 
releases represent what can be captured in the allotted time from the designated area.

Overall, the success of most transplantation efforts has been limited in size of areas newly occupied, or by straggling or abrupt failures (Leopold 1933). There has also been an overall lack of scientific rigor in transplantation projects and a lack of reporting on the many releases attempted. We may have been fortunate as ptarmigan seem able to survive in most alpine and tundra habitats that have topographic relief, areas with suitable rocks for cover, short growing vegetation, and lingering snowfields. These areas are typically cool and moist, and are without substantial vegetation taller than $1.5 \mathrm{~m}$. Winter and early spring appear to be most important for ptarmigan in terms of food (buds of deciduous shrubs such as Alnus, Betula, Salix, and ericaceous heaths), and low predation pressure (Sandercock et al. 2011). Some alpine and tundra areas appear to support very low densities of ptarmigan, especially during the breeding period. High levels of snowfall and persistent snow cover into late May and early June can be restrictive for breeding territories unless there is topographic relief. This emphasizes the need for pre-release evaluations of sites where ptarmigan are to be released. Written evaluations of prospective release sites, as well as protocols to be followed and publication of results are needed for all translocations.

\section{RECOMMENDATIONS}

1. Careful planning based on the biological knowledge of the species being translocated is essential well in advance of implementation.

2. Sites should be evaluated prior to release.

3. Capture techniques should be considered.

4. We recommend holding live birds in cool and predator-safe cages or boxes, and for no more than 2 days; melons as a source of water and nutrients are recommended.

5. Transport should be rapid and direct with field assistance at both departure and arrival points.

6. A minimum of 40 wild-caught birds should be released within the first year.

7. Balanced or female-biased sex ratios may be best but are not critical.

8. The optimum time for releases is during the spring breeding period.

9. Releasing mated pairs is desirable.

10. Fall releases of birds, especially those less than 8 weeks of age, should be discouraged.

11. All birds released should be marked with bands or other inconspicuous markers, but not radios.

12. Appropriate data (measurements such as wing length, body mass, blood samples) should be obtained for each bird prior to release.

13. Placement of birds into suitably-appearing breeding habitat is desirable.

14. Follow up surveys at 1-, 3-, and 5-year intervals are important to evaluate the immediate response of the translocated birds.

15. Reports must be prepared and followed by peer-reviewed publications. 


\section{ACKNOWLEDGMENTS}

We thank personnel of the Colorado Division of Wildlife, especially W. W. Sandfort and G. E. Rogers, for supporting translocations of White-tailed Ptarmigan from Colorado. R. W. Hoffman and K. M. Giesen were helpful in translocations and follow up surveys in Colorado and Utah. G. V. Byrd facilitated the logistics and approval for the work on Attu and Agattu. We also thank the US Coast Guard for use of facilities on Attu.

\section{Literature Cited}

Bellinger, M. R., J. A. Johnson, J. E. TophFER, AND P. O. DUNN. 2003. Loss of genetic variation in Greater Prairie Chickens following a population bottleneck in Wisconsin, USA. Conservation Biology 17:717-724.

Boag, D. A., And M. A. Schroeder. 1992. Spruce Grouse (Falcipennis canadensis). In A. Poole and F. Gill (Eds.). The Birds of North America, no. 5. Academy of Natural Sciences, Philadelphia, and American Ornithologist's Union, Washington, DC, USA.

Bouzat, J. L., H. H. Cheng, H. A. Lewin, R. L. Westemeier, J. D. Brawn, AND K. N. PAIGE. 1998. Genetic evaluation of a demographic bottleneck in the Greater Prairie Chicken. Conservation Biology 12:836843.

Braun, C. E. 1971. Habitat requirements of Colorado White-tailed Ptarmigan. Proceedings of the Western Association of State Game and Fish Commissioners 51:284292.

Braun, C. E. 1993. White-tailed Ptarmigan habitat investigations in northeast Oregon. Oregon Birds 19:72-73.

Braun, C. E. AND G. E. Rogers. 1971. The White-tailed Ptarmigan in Colorado. Technical Publication 27. Colorado Division of Game, Fish and Parks, Fort Collins, Colorado, USA.

Braun, C. E., D. H. Nish, AND K. M. Giesen. 1978. Release and establishment of White- tailed Ptarmigan in Utah. Southwestern Naturalist 23:661-668.

Braun, C. E., R. K. Schmidt, JR., AND G. E. Rogers. 1973. Census of Colorado Whitetailed Ptarmigan with tape-recorded calls. Journal of Wildlife Management 37:90-93.

Connelly, J. W., M. W. Gratson, and K. P. REESE. 1998. Sharp-tailed Grouse (Tympanuchus phasianellus). In A. Poole and F. Gill (Eds.). The Birds of North America, no. 354. Academy of Natural Sciences, Philadelphia, and American Ornithologist's Union, Washington, DC, USA.

Ewen, J. G., And D. P. Armstrong. 2007. Strategic monitoring of reintroductions in ecological restoration programmes. Ecoscience 14:401-409.

Frederick, G. P., AND R. J. Gutierrez. 1992. Habitat use and population characteristics of White-tailed Ptarmigan in the Sierra Nevada, California. Condor 94:889-902.

Gabrielson, I. N., AND S. G. Jewett. 1940. Birds of Oregon. Oregon State College, Corvallis, Oregon, USA.

Giesen, K. M. 1998. Lesser Prairie-Chicken (Tympanuchus pallidicinctus). In A. Poole and F. Gill (Eds.). The birds of North America, no. 364. Academy of Natural Sciences, Philadelphia, and American Ornithologist's Union, Washington, DC, USA.

Giesen, K. M., And C. E. Braun. 1993. Natal dispersal and recruitment of juvenile White-tailed Ptarmigan in Colorado. Journal of Wildlife Management 57:72-77.

Griffin, B., J. M. Scott, J. W. CARpenter, AND C. REED. 1989. Translocation as a species conservation tool: Status and strategy. Science 245:477-480.

Hannon, S. J., P. K. EAson, AND K. Martin. 1998. Willow Ptarmigan (Lagopus lagopus). In A. Poole and F. Gill (Eds.). The birds of North America, no. 369. Academy of Natural Sciences, Philadelphia, and American Ornithologist's Union, Washington, DC, USA.

HoffMAn, R. W., AND K. M. Giesen. 1983. Demography of an introduced population 
of White-tailed Ptarmigan. Canadian Journal of Zoology 61:1758-1764.

Hoffman, R. W., W. D. SNyder, G. C. Miller, AND C. E. BRAun. 1992. Reintroductions of Greater Prairie-Chickens in northeastern Colorado. Prairie Naturalist 24:197-204.

Kaler, R. S. A., S. E. Ebbert, C. E. Braun, AND B. K. SANDERCOCK. 2010. Demography of a reintroduced population of Evermann's Rock Ptarmigan in the Aleutian Islands. Wilson Journal of Ornithology 122:1-14.

LEOPOLD, A. 1933. Game Management. Charles Scribner's Sons, New York, USA.

Martin, K., AND C. A. Wright. 1993. Estradiol cypionate (ESP) markedly improves survival of Willow Ptarmigan in captivity. Condor 95:211-217.

Moran, R. J., and W. L. Palmer. 1963. Ruffed Grouse introductions and population trends on Michigan islands. Journal of Wildlife Management 27:606-614.

Musil, D. D., J. W. Connelly, and K. P. REESE. 1993. Movements, survival, and reproduction of Sage Grouse translocated into central Idaho. Journal of Wildlife Management 57:85-91.

Reese, K. P., And J. W. Connelly. 1997. Translocation of Sage Grouse Centrocercus urophasianus in North America. Wildlife Biology 3:235-241.

REyNOLDS, M. H., N. E. SEAVy, M. S. VeKasy, J. L. KlaVitTER, AND L. P. LANiaWE. 2008. Translocation and early post-release demography of endangered Laysan Teal. Animal Conservation 11:160-168.

Rusch, D. H., S. DeStefano, M. C. REYNOLDS, AND D. LAUTEN. 2000. Ruffed Grouse (Bonasa umbellus). In A. Poole and F. Gill (Eds.). The Birds of North America, no. 515. Academy of Natural Sciences, Philadelphia, and American Ornithologist's Union, Washington, DC, USA.

SANDERCock, B. K., E. B. Nilsen, H. Brøseth, and H. C. Pedersen. 2011. Is hunting mortality additive or compensatory to natural mortality? Effects of experimental harvest on the survival and cause-spe- cific mortality of Willow Ptarmigan. Journal of Animal Ecology 80:244-258.

Schroeder, M. A., AND L. A. RobB. 1993. Greater Prairie-Chicken (Tympanuchus cupido). In A. Poole and F. Gill (Eds.). The Birds of North America, no. 36. Academy of Natural Sciences, Philadelphia, and American Ornithologist's Union, Washington, DC, USA.

Snyder, J. W., E. C. Pelren, AND J. A. CrawFORD. 1999. Translocation histories of prairie grouse in the United States. Wildlife Society Bulletin 27:428-432.

SteEn, N. C. 1995. Matanuska Valley Ruffed Grouse transplant, 1988-1990. Final Report. Alaska Department of Fish and Game, Juneau, Alaska, USA.

Steen, N. C. 1999. Kenai Peninsula Ruffed Grouse transplant, 1995-1997. Final Report. Alaska Department of Fish and Game, Juneau, Alaska, USA.

Toepfer, J. E., R. L. ENG, AND R. K. ANDERSON. 1990. Transplanting prairie grousewhat have we learned? Transactions of the North American Wildlife and Natural Resources Conference 55:569-579.

Wang, G., N. T. Hobbs, K. M. Giesen, H. GALBRAITH, D. S. OJIMA, AND C. E. BRAUN. 2002. Relationships between climate and population dynamics of White-tailed Ptarmigan Lagopus leucurus in Rocky Mountain National Park, Colorado, USA. Climate Research 23:81-87.

Zimmerman, C. E., N. Hillgruber, S. E. BurRiL, M. A. St. Peters, AND J. D. Wetzel. 2005. Offshore marine observations of Willow Ptarmigan, including water landings, Kuskokwim Bay, Alaska. Wilson Bulletin 117:12-14.

Zwickel, F. C. 1992. Blue Grouse (Dendragapus obscurus). In A. Poole and F. Gill (Eds.). The Birds of North America, no. 15 Academy of Natural Sciences, Philadelphia, and American Ornithologist's Union, Washington, DC, USA.

ZWickel, F. C., AND J. F. BENDELl. 1967. A snare for capturing Blue Grouse. Journal of Wildlife Management 31:202-204. 